\title{
Anton van der Lem, L'Automne du Moyen Âge à Leyde
}

\author{
Maria Colombo Timelli
}

\section{(2) OpenEdition}

\section{Journals}

\section{Édition électronique}

URL : http://journals.openedition.org/studifrancesi/1276

DOI : 10.4000/studifrancesi. 1276

ISSN : 2427-5856

\section{Éditeur}

Rosenberg \& Sellier

\section{Édition imprimée}

Date de publication : 1 décembre 2015

Pagination : 571

ISSN : 0039-2944

\section{Référence électronique}

Maria Colombo Timelli, « Anton van der Lem, L'Automne du Moyen Âge à Leyde », Studi Francesi [En ligne], 177 (LIX | III) | 2015, mis en ligne le 01 décembre 2015, consulté le 06 janvier 2021. URL : http:// journals.openedition.org/studifrancesi/1276 ; DOI : https://doi.org/10.4000/studifrancesi.1276

Ce document a été généré automatiquement le 6 janvier 2021.

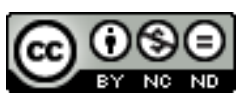

Studi Francesi è distribuita con Licenza Creative Commons Attribuzione - Non commerciale - Non opere derivate 4.0 Internazionale. 


\title{
Anton van der Lem, L'Automne du Moyen Âge à Leyde
}

\author{
Maria Colombo Timelli
}

\section{RÉFÉRENCE}

ANTON VAN DER LEM, L'Automne du Moyen Âge à Leyde, in «Publication du Centre Européen d'Études Bourguignonnes (XIV -XVI ${ }^{\mathrm{e}}$ s.)», 54, 2014, pp. 179-190.

1 Rédigées par un conservateur de la Bibliothèque de l'Université de Leyde, ces belles pages sont consacrées à Johan Huizinga. Elles font d'abord le point sur les études les plus récentes qui lui ont été consacrées: des thèses surtout, ainsi que l'édition de sa correspondance; suit la présentation chronologique de sa bibliographie, enrichie de détails biographiques parfois très vifs (ainsi, sa visite à l'exposition de la Toison d'or en 1907 à Bruges, où il se rendit à bicyclette avec sa jeune épouse); surtout la genèse de l'Automne du Moyen Âge, sa réception dans l'Europe entière, ses nombreuses traductions, intéresseront certainement les lecteurs de notre Rassegna. L'article est enrichi de belles photos en couleur, parmi lesquelles on ne peut pas manquer de signaler la photo de la seule page conservée du manuscrit de Herfsttij der Middeleeuwen (p. 186). 